\title{
The Concept of Criminal Imposition Through Compensation for The Victim in The Future Within The Juvenile Criminal Justice System
}

\author{
Dwi Agus Prianto \\ \{dwieagus99@gmail.com\} \\ Doctor of Law, Universitas Jayabaya, Jakarta, Indonesia
}

\begin{abstract}
Violation of values and norms prevailing in society is committed by adults and children as well. Violation against the law by children needs special treatment to avoid negative impact of the punishment on children's development. In addition, there is a need for legal diversion in the imposition of crimes in violation against law committed by children, including the provision of compensation to victims as a manifestation of restorative justice, which has never been carried out by courts or judges in Indonesia. This research is a normative legal research done using a conceptual approach, a statutory approach and a case approach. This research describes the object of research critically through qualitative analysis. The results of the study showed that the concept of imposing criminal punishment through future compensation can be done in the penal mediation process applied in the juvenile criminal justice system, starting from the investigation and prosecution. If the requirements that include perpetrators admitting their actions, promising not to repeat, apologizing to the victim and acting responsible and the victim is willing to accept an apology and is willing to conduct deliberation or negotiation, while community representatives also demand for deliberation, the compensation concept can be applied. Special conditions for penal mediation are applied to cases of minor qualifications. The results of the mediation agreement are attached in the case file submitted to the court. In the trial stage, the Judge can process the penal mediation in the mediation room after examining the victim, witnesses, evidence and children before hearing the demands of the Public Prosecutor.
\end{abstract}

Keywords: Diversion; Children, Imposition of Criminal Acts

\section{Introduction}

The provision of punishment or sanctions and the legal process in law violations by children is indeed different from those committed by adults considered responsible being and accountable for all their actions [1]. Children are individuals who have not yet understand the notion of responsibility, and therefore, in the legal process and punishment, children must receive a special treatment that distinguishes them from adults.

Based on records from the 2015 National Commission for Child Protection (Komisi Perlindungan Anak-KPA), 1,851 complaint reports concerning juvenile delinquency were submitted to the court of law throughout 2014 in Indonesia. 52\% of them were theft, followed 
by violence, rape, drugs, and assault. Around $89.8 \%$ ended up being convicted and sentenced. The data demonstrates a large number of children who were imprisoned [2] .

In light of that, Law Number 11 of 2012 concerning the Juvenile Criminal Justice System (from now on abbreviated as SPPA or Sistem Peradilan Pidana Anak), which is a replacement for Law Number 3 of 1997 concerning Juvenile Court, has explicitly regulated restorative justice and diversion aiming to avoid and refrain children from the judicial process to prevent stigma against juvenile delinquents and for the sake of a better reintegration into the society [3]. Furthermore, it accommodates the principles of child protection, especially the principle of nondiscrimination, which prioritizes the child's best interests and the right to life, survival, and development [4]. Therefore, the participation of all parties is needed in accomplishing this matter.

Based on Article 1 point 6 of the SPPA Law, restorative justice is the settlement of criminal cases by involving the perpetrator, victim, family of the perpetrator and/or victim, and other relevant parties to commit in seeking a fair solution by emphasizing restoration instead of retaliation. Furthermore, Article 5 paragraph (1) also encourages that the juvenile criminal justice system to prioritize a restorative justice approach. Restorative justice referred to in the SPPA Law is the obligation to make a diversion. According to Romli Atmasasmita, diversion is the possibility of the judge stopping or terminate the examination of cases and the children themselves during the examination process before the trial. Meanwhile, Article 1 point 7 of the SPPA Law states that diversion is the transfer of the settlement of children's cases from the criminal justice process to another resolution outside of the criminal justice system.

The SPPA Law has regulated diversion that destigmatizes juveniles that results from the judicial process they have undergone. The use of the diversion mechanism is bestowed upon the law enforcers (police, prosecutors, judges, other institutions) in dealing with juveniles without proceeding to a formal court. Its application is intended to reduce the negative impact of children's involvement in a judicial process. The objectives of diversion as stated in Article 6 of the SPPA are as followed [5]:

1. Achieving peace between victims and juvenile perpetrators

2. Resolving juvenile delinquency cases outside of the judicial process

3. Preventing children from being deprived of their liberty

4. Encouraging the community to participate

5. Instilling a sense of responsibility in children

The implementation of diversion must also include the consent of the juvenile perpetrators, their parents, or guardians [6]. It should also cooperate with some communities for programs such as supervision, guidance, recovery, and compensation to victims.

The form of handling the case of juvenile delinquency emphasizes the best interests of the child [7]. Therefore, decisions taken by judges must be fair and proportional, not solely based on legal considerations, but also considering various other factors, such as environmental conditions, the children's social status, and their family and the surrounding circumstances. In addition to paying more attention to the child's interests, the judge in their decision/making must also attend to the provision of compensation to the victim as the implementation of diversion in the juvenile justice process. 


\section{Research Methods}

This research method uses normative legal research through a conceptual approach, a statutory approach, and a case approach. This research is descriptively analytical and describes something that is the object of critical research through qualitative analysis.

\section{Results and Discussion}

A breakthrough in penal mediation as an instrument of restorative justice involves the judges, prosecutors, and investigators based on a Joint Decree of the Chief Justice of the Supreme Court, the Attorney General, the National Police Chief, the Minister of Law and Human Rights, the Minister of Social Affairs, and the Minister of Women and Children Empowerment regarding the handling of juveniles (Anak yang Berhadapan dengan Hukum$\mathrm{ABH}$ ) which emphasizes the restorative justice principles [8].

A comprehensive analysis of all aspects will have an impact on the judge's decisionmaking. The judge considers the facts and background of the child's actions in providing alternative solutions to the mediated parties. This form of mediation is different in civil cases where the mediator does not discuss the subject matter of the case but begins by identifying the core problems regardless of their moral value. In juvenile criminal cases, the judge is already aware of the facts that were revealed at the trial and its chronological background from the Community Research Report (Penelitian Kemasyarakatan-Litmas) submitted by Social Supervisor of Penitentiary (Pembimbing Kemasyarakatan Balai Pemasyarakatan-PK Bapas) at the beginning of the trial. The judge can also ask questions directly in the trial for convenience in unearthing concealed matters from the relevant parties. The involvement of community representatives on a casuistic basis is also an aspect that the mediator must consider.

To achieve this goal of protection, it is necessary to strive for a condition in which every child can exercise their rights and obligations as much as possible in assuming as citizens. Providing children's rights and responsibilities also certainly includes juveniles. It correlates with the Middle Range Theory in this study in which the Juvenile Criminal Justice System can resolve cases through penal- and non-penal justice.

In addition to the restorative justice process and the diversion trial, juvenile criminal cases can also be settled formally or through a penal trial in court [9]. The juvenile criminal justice process in court can be based on the provisions of Article 7 number (2) letters a and b in conjunction with Article 9 number (2) letters a, b, c, and d of the Juvenile Criminal Justice System Act. The law essentially affirms that: a) the sentencing for more than seven years is for recidivist juveniles and not applicable for first-time offenders, b) diversion is rejected by the victim and/or the family of the victim, and the case is not a violation, misdemeanour, but the crime with victims, and loss experienced by the victim surpass the value of the local minimum wage.

The non-penal justice pathway is a model of juvenile criminal justice which concerns a non-litigation manner. The purpose of this trial is preventive and aims to protect the interests and future of children, prioritize the principle of the best interest for the juveniles, and override the ultimum remedium principle. A non-litigation justice against juveniles is based on the severity of the delinquency. It depends whether they commit an infraction, misdemeanour, or minor delinquency that has no mens rea behind it. Normatively, the severity of specific 
delinquency does not meet the elements of Article 7 paragraph (2), in conjunction with the aforementioned Article 9 paragraph (2) of the SPPA Law.

The meaning of a criminal act as conveyed by Marc Ancel is not only a manifestation of the recognition and respect for human rights, which have become the main principles in every state of law but also a purposive balancing effort the rights of victims, which normatively still unrecognized by the criminal justice system [10]. With this perspective that views a criminal act as not merely a violation of state law but also an act that causes harm to the community, especially victims who directly experience the suffering, it is convenient to understand that the victims are not the state's responsibility. Instead, however, the focus lies on the victim by providing compensation.

In resolving a crime through a restorative approach, there is room for each party involved in the settlement circle and to reveal the nature of the crime and its rationale and its following consequences and the restorative effort. The circle of settlement is carried out through discussion and dialogue that create equal opportunities for resolution without having to incite a novel problem that is often found in the criminal justice system in general, such as the sanctioning imposition of imprisonment, which often causes a prolonged embarrassment for the families of victims and perpetrators and hinders the rehabilitation process for perpetrators in the future.

\section{Conclusion}

The sentencing of juveniles is often not following the purpose of punishment, guided by the judicial policy of juvenile criminal judges that can reflect the value of substantive justice in implementing juvenile criminal justice with a double-track (Criminal Justice System for Juvenile Delinquency), which is based on Pancasila values on progressive justice. The parties execute the concept of imposing criminal penalties through compensation for infraction cases in the future through a juvenile penal mediation process. It can be conducted from the investigation stages to the prosecution If it meets some required elements. Firstly, the perpetrator claims culpability of their actions and promises not to repeat the act, apologize to the victim, and assume responsibility. Secondly, the victim is willing to accept the apology and conduct mediation or negotiation. Thirdly, the community representative supports the penal mediation. However, it is only done for criminal acts with light qualifications.

\section{References}

[1] Anatasia, Zulita, 'Diversion Against Crime by Children Confronting the Law to Achieve Restorative Justice', Pancasila and Law Review, 1.2 (2021) <https://doi.org/10.25041/plr.v1i2.2120>

[2] Hafrida, Hafrida -, 'Restorative Justice In Juvenile Justice To Formulate Integrated Child Criminal Court', Jurnal Hukum Dan Peradilan, 8.3 (2019) <https://doi.org/10.25216/jhp.8.3.2019.439-457>

[3] Hardjaloka, Loura, 'Criminal Justice System of Children: An Overview Restorative Justice Concept in Indonesia and Other Countries', Journal of Dinamika Hukum, 15.1 (2015)

[4] Listyarini, Dyah, 'Juvenile Justice System Through Diversion And Restorative Justice Policy', Diponegoro Law Review, 2.1 (2017) <https://doi.org/10.14710/dilrev.2.1.2017.168-184>

[5] Negara, Arman Sukma, 'Diversion As A Crime Solution Towards Child Crime Prepertrator', Ius Poenale, 2.1 (2021) <https://doi.org/10.25041/ip.v2i1.2204>

[6] Novita Erdianti, Ratri, Sholahuddin Al-Fatih Ratri Novita Erdianti, and Sholahuddin Al-Fatih, 'Fostering as an Alternative Sanction for Juveniles in the Perspective of Child Protection in Indonesia', Journal of Indonesian Legal Studies, 4.1 (2019) 
[7] Ramada, Diandra Preludio, 'Reality Of Protection For Sexual Violence Victims: Comprehensive Protection Analysis For Sexual Violence Victims', IJCLS (Indonesian Journal of Criminal Law Studies), 2.2 (2017) <https://doi.org/10.15294/ijcls.v2i2.12324>

[8] Syahrin, Muhammad Alvi, 'The Immigration Crime and Policy: Implementation of PPNS Authorities on Investigation', Journal of Indonesian Legal Studies, $3.02 \quad$ (2018) <https://doi.org/10.15294/jils.v3i02.27512>

[9] Law Number 11 of 2012 concerning the Juvenile Criminal Justice System 